\title{
Ege Bölgesi’nde Sıcaklık Ekstremlerinde Gözlenen Değişim ve Eğilimlerin Değerlendirilmesi
}

\author{
Assessment of Variability and Trends in Temperature Extremes over Aegean \\ Region of Turkey
}

\author{
Ecmel ERLAT ${ }^{\mathbf{1}}$, Doğukan Doğu YAVAŞLI ${ }^{1}$ \\ ${ }^{1}$ Ege Üniversitesi Edebiyat Fakültesi Coğrafya Bölümü, İzmir
}

\begin{abstract}
Özet: Çalı̧̧mada, Ege Bölgesi'nde 10 istasyonda 1939-2008 yılları arasında 6 farklı sıcaklık indisine göre ekstrem sicaklıklarda görülen değişim ve eğilimler Mann-Kendall trend analizine göre incelenmiştir. Kullanılan ekstrem sicaklık indisleri soğuk gün ve gece saylları, sicak gün ve gece sayılart ile yaz ve tropikal gün sayllarıdır. Sonuçlar, bölgede yıllık soğuk gün ve gece sayılarının istatistiki olarak anlamlı olmayan genel bir azalma ĕgilimi içinde olduğunu göstermektedir. Bölgede sicaklık ekstremleri içinde en belirgin değişim yıllık sıcak gün ve sıcak gece sayılarında gözlenmektedir. Mann-Kendall trend analizinin sonuçlarına göre, yıllık sicak gün ve sicak gece sayllarında özellikle son 35 yılda belirginleşen artış eğilimi istatistiki olarak tüm istasyonlarda anlamlıdır. Ege Bölgesi'nde yıllık tropikal gün ve yaz günü sayılarında 1940'lı yıllardan 1970'li yilların ilk yarısına kadar olan dönemde önemli bir değişim gözlenmemektedir. Ancak 1970'li yılların ikinci yarısından 2008 yılına kadar olan dönemde istatistiki olarak anlamlı artış eğilimleri egemen olmaktadır. Bu durum Ege Bölgesi'nde sicakliklardaki soğuk ekstremlerin gerçekleştiği gün sayılarındaki azalmadan çok, sıcak ekstremlerin yaşandı ̆̆ gün sayıların arttığını ve termik koşulların daha sicak değerlere doğru kaydiğını göstermektedir.

Anahtar Kelimeler: Ekstrem iklim indisi, Trend analizi, Günlük slcaklık, Ege Bölgesi.
\end{abstract}

\begin{abstract}
In this study, extreme temperatures of Aegean region were investigated via 6 temperature indices and non-parametric Mann-Kendall rank correlation test between the years 1939-2008 at 10 meteorological stations. These climate extreme indices are the annual numbers of cold day, cold night, warm day, warm night, summer day, and tropical day. Results showed that the annual numbers of cold day and cold night are generally in a decreasing trend that is statistically insignificant. The most distinctive change of temperature extremes in the region is observed for annual numbers of warm day and warm night. Depending on the outcome of Mann-Kendall trend analysis, the increasing trend for annual numbers of warm day and night which is becoming evident in last 35 year period is statistically significant for all stations. No significant change has been observed for annual numbers of tropical day and summer day between the years 1940's and first half of 1970's. However, statistically significant increasing trends are dominant for the period between the second half of 1970's and 2008. This situation indicates that an increase in warm extremes rather than with a decrease in cold extremes at the Aegean region and thermal conditions are shifting towards warmer conditions.
\end{abstract}

Key words: Extreme climate indices, Trend analysis, Daily temperature, Aegean region.

\section{Giriş}

1880'li y1llardan itibaren antropojenik nedenlere bağlı olarak atmosferin doğal sera etkisinin kuvvetlenmesi, küresel ölçekte iklim koşullarında birtakım değişiklikleri de beraberinde getirmiştir. Günümüzde Sanayi Devrimi öncesi döneme göre, başta sıcaklık olmak üzere birçok iklim elemanın ortalama değerlerinde artış veya azalış yönünde değişim ve eğilimler gözlenmektedir. İklim değişmeleri ile ilgili olarak özellikle 2000'li yıllardan sonra yoğunlaşan çalışmalar, ortalamalar yanında ekstrem (aşırı veya uç) iklim olaylar da benzer eğilimlerin olduğunu ortaya koymaktadır. 
İklim modelleri, küresel sıcaklıklardaki artış eğilimi ve buna bağlı olarak hidrolojik döngünün hızlanması ile ilişkili olarak, içinde bulunduğumuz yüzyılda sıcak ve soğuk hava dalgaları, şiddetli yağışlar veya kuraklıklar gibi ekstrem iklim olaylarının sıklığı veya şiddetinde artışlar öngörmektedir (IPCC, 2007). Güney ve Orta Amerika, Afrika ve Güneydoğu Asya gibi alanlarda yeterli uzunlukta veri setlerinin bulunmaması, ekstrem iklim olayları konusunda küresel ölçekte veri elde edilmesini güçleştirmektedir. Ancak özellikle bölgesel ölçekte yapılan çalışmalar, öngörüler doğrultusunda ekstrem sıcaklıkların, günlük maksimum yağışlar ile tropikal siklonların frekansının ve şiddetinin değiştiğini göstermektedir. Elde edilen eğilimler bölgeden bölgeye değişmekle birlikte belirlenen değişim ortalama değerlerdekine göre çok daha hızlı gerçekleşmektedir (Frich vd., 2002; Kiktev vd., 2003). Gerekli önlem ve hazırlıklar yapılmadığında meteorolojik karakterli afetlere dönüşen ekstrem iklim olaylarının sıklığg ve frekansındaki artışlar, ekolojik sistemler yanında insan yaşamını olumsuz etkileme potansiyeline sahiptir.

Sıcaklık ekstremleri konusunda yapılan çalışmalar ele alındığında, özellikle 20. yüzyılın son çeyreğinde daha belirgin olmak üzere, değerlerin değiştiğini ortaya koymaktadır. Örneğin küresel ölçekte dağılım gösteren 200 istasyonun 1951-2003 döneminde kaydedilen günlük sıcaklıkları üzerine 16 indisin kullanılması ile yapılan incelemeler, istasyonlarda soğuk gece ve soğuk günlerin istatistiki olarak anlamlı olmak üzere azalma eğilimi gösterdiğini ortaya koymuştur. Buna karşıllk sicak geceler, sıcak günler ve yaz günü sayıları birçok istasyonda artma eğilimi göstermektedir. Ayrıca analizler, günlük minimum sıcaklıklardaki belirlenen eğilimlerin çok daha belirgin olduğu yönündedir (Alexander vd., 2006).

Avrupa için yapılan çalışmalar genel olarak değerlendirildiğinde özellikle kıtanın batı ve güney bölgelerinde son 30 yıl içinde soğuk günlerin azaldığı, yaz ve tropikal gün sayılarının arttığı, sicak hava dalgalarının frekansının ise yükseldiği sonucuna ulaşılmaktadır. Örneğin İspanya'da rasatları 1894 yılına uzanan 22 istasyonun sicaklık gözlemleri incelendiğinde, 2003 yılına kadar sıcak günlerin sayısındaki artıştan çok, soğuk günlerin sayısının azaldığı belirlenmiştir. Ancak 1973 yılından itibaren Akdeniz'e komşu istasyonlarda daha belirgin olmak üzere sıcak günlerin sayısında belirgin bir artış gözlenmiştir (Brunet vd., 2006). Orta ve Doğu Avrupa'da yer alan 32 istasyonun 1946-2001 yılları arasında ekstrem sıcaklık ve yağış olayları incelendiğinde, sıcaklıkların 1970'li yılların ortalarına kadar devam eden bir soğuma eğilimi sergilediği, bu tarihten sonra özellikle sıcak günler, yaz günleri, sıcak gecelerin yıllık sayılarının her on yıl için 6 gün gibi yüksek bir oranda arttığı, sıcak dalgalarının süresinin ise uzadığ 1 belirlenmiştir (Bartholy ve Pongracz, 2007). Yunanistan'da günlük maksimum sıcaklığın $30{ }^{\circ} \mathrm{C}$ geçtiği tropikal gün sayıları, 1955-1976 arası dönemde azalma, 1976-2000 arası dönemde ise artma eğilimi göstermiştir. Artış eğilimin en yüksek olduğu istasyonlar aynı zamanda Yunanistan'ın kentsel gelişmeye bağlı kuvvetli 1sı adalarının oluştuğu istasyonlardır (Nastos ve Matzaeakis, 2008). Yunanistan'da yer alan 23 istasyonda iklim ekstremlerinin incelediği bir başka çalışmada, 1955-2002 döneminde istasyonların \%74'ünde sıcak geceler, tropikal geceler sayılarında belirgin bir artışın olduğunu belirtilmektedir. İncelenen istasyonlarda ekstrem minimum sıcaklıklardaki değişimin ekstrem maksimum sıcaklıklara göre çok daha hızlı gerçekleştiği ifade edilmektedir. Özellikle yaz aylarında 1955-1978 ve 1979-2002 dönemlerinde sıcak geceler sayısındaki artış dikkat çekicidir. Bu durum bölge üzerindeki etezyen rüzgarlarının zayıflaması ile açıklanmaktadır (Kioutsioukis vd., 2009). Doğu Akdeniz'de yer alan 246 istasyonun sıcaklık gözlemlerine göre 19602006 döneminde sıcak dalgalarının incelendiği bir başka çalışma, bölgede 1960'lı yıllardan itibaren sıcak gün ve geceler (günlük maksimum ve minimum sıcaklıkların 95. persantil aralığ 1 içinde kaldığ gün) ile sıcak dalgalarının sayısı, süresi ve şiddetinin önemli ölçüde arttığını ortaya koymaktadır. Sıcak dalgalarındaki değişimin en şiddetli olduğu alanlar ise Türkiye'de Karadeniz bölgesinin doğusu, batı, güneybatı ve orta Anadolu ile Balkanların batısıdır (Kuglitsch vd., 2010). 
Türkiye'de sıcaklık değişimi ve ekstrem sıcaklıklar üzerine yapılan çalışmalar sıcaklıkların yükselme ve ekstrem değerlerin değişme eğilimi içinde olduğunu göstermektedir. Örneğin minimum ve maksimum sıcaklıklar ile günlük sıcaklık farklarının değişim ve eğilimleri üzerine yapılan bir çalışma, Türkiye'nin büyük bir bölümünde 1992 yılına kadar maksimum ve minimum sıcaklık dizilerinde -ilkbahar dışında- genel bir azalma eğiliminin egemen olduğunu ancak bu tarihten sonra sıcaklıkların özellikle ilkbahar ve yaz mevsimlerinde artış eğilimi gösterdiğini ortaya koymuştur (Türkeş vd., 2002). Türkiye'de 100 istasyonun sıcaklık gözlemlerinin 27 ekstrem indisine göre 19712004 dönemi için RclimDex yazılımından yararlanılarak incelendiği çalışmada, Türkiye'de donlu günler sayılarının azaldığı buna karşılık yaz günleri ve tropik gece sayılarının arttığı sonucuna ulaşılmıştır. İstasyonlarda soğuk gün ve soğuk gece sayısı azalırken; sıcak gün ve sıcak gece sayıları çoğu \% 5 seviyesinde anlamlı olmak üzere (ortalama artış 26 gün/100 yıl) ise artmaktadır (Şensoy vd., 2008).

\section{Yöntem}

Bu çalışmada Ege Bölgesi'nde yer alan 10 istasyonun 1939-2008 yılları arasında kalan 70 yıla ait günlük minimum ve maksimum sıcaklıkları incelenmiştir. İstasyonların seçiminde rasat sürelerinin uzunluğu, kesintisiz olması ve istasyonların yer değiştirmemiş olması ölçütleri esas alınmıştır (Çizelge1).

Çizelge 1. Çalışmada kullanılan istasyonların coğrafi konumları ve rasat süreleri.

\begin{tabular}{|l|c|c|c|c|}
\hline \multicolumn{1}{|c|}{ İstasyonlar } & Gözlem süresi & Enlem & Boylam & Yükselti (m) \\
\hline Kütahya & $1939-2008$ & $39^{\circ} 25^{\prime}$ & $29^{\circ} 58^{\prime}$ & 969 \\
\hline Uşak & $1939-2008$ & $38^{\circ} 41^{\prime}$ & $29^{\circ} 24^{\prime}$ & 919 \\
\hline Afyon & $1939-2008$ & $38^{\circ} 45^{\prime}$ & $30^{\circ} 32^{\prime}$ & 1033 \\
\hline Dikili & $1941-2008$ & $39^{\circ} 04^{\prime}$ & $26^{\circ} 53^{\prime}$ & 3 \\
\hline Akhisar & $1939-2008$ & $38^{\circ} 54^{\prime}$ & $27^{\circ} 49^{\prime}$ & 92 \\
\hline Manisa & $1939-2008$ & $38^{\circ} 37^{\prime}$ & $27^{\circ} 26^{\prime}$ & 71 \\
\hline İzmir & $1939-2008$ & $38^{\circ} 23^{\prime}$ & $27^{\circ} 04^{\prime}$ & 28 \\
\hline Aydın & $1940-2008$ & $37^{\circ} 51^{\prime}$ & $27^{\circ} 51^{\prime}$ & 56 \\
\hline Muğla & $1939-2008$ & $37^{\circ} 13^{\prime}$ & $28^{\circ} 22^{\prime}$ & 646 \\
\hline Bodrum & $1939-2008$ & $37^{\circ} 03^{\prime}$ & $27^{\circ} 26^{\prime}$ & 26 \\
\hline
\end{tabular}

Ekstrem (uç ya da aşırı) iklim olayları, herhangi bir istasyondaki bir iklim elemanının değerlerinde istatistiksel dağılıma göre ender görülen olaylardır. Ekstrem iklim olaylarının özellikleri bir istasyondan diğerine değişebilmektedir. Bu nedenle 2001 y1lında Dünya Meteoroloji Örgütü tarafindan koordine edilen bir iklim komisyonu (Climatology and the Expert Team on Climate Change Detection, Monitoring and Indices -ETCCDMI) tüm dünyada ekstrem olayların incelenebilmesi ve elde edilen sonuçların bir standart göre karşılaştırılabilmesi için 27 indis önermiştir (Peterson vd., 2001). Bu indislere göre bir iklim olayının "ender" olarak tanımlanırken, incelenen iklim elemanının oluşturduğu veri setinde değerler normal dağılıma göre 10'uncu veya 90'ıncı persantili içinde yer alması esas alınmaktadır. "Ender" olma durumu, çeşitli istatistiksel dağılım fonksiyonları temel alınarak, dağılımın iki yanlı biçimine göre \%90 ya da \%95 güven düzeyleri yardımıyla da tanımlanabilmektedir. Bunun yanı sıra ekstrem iklim olaylarının tanımlanmasında don olaylı gün sayıları, yaz günleri veya tropikal günlerde olduğu gibi belli eşik değerler de dikkate alınabilmektedir. Belirlenen bu indisler hem küresel hem de bölgesel çalışmalarda kullanılmıştır.

Bu çalışmada Ege Bölgesinde yer alan 10 istasyonun 1939-2008 döneminde kaydedilen günlük maksimum ve minimum sıcaklıklarının oluşturduğu veri setlerine 6 indis uygulanmıştır. (Çizelge 2). 
İstasyonların yıllık soğuk ve sıcak geceler ile soğuk ve sıcak gün sayılarının belirlenmesinde, her istasyona özgü özel eşik değerleri esas alınmıştır. Bu eşik değerlerinin hesaplanabilmesi için istasyonların rasat süresi içinde ölçülen günlük maksimum ve minimum sıcaklıklarının oluşturduğu sicaklık dizilerinde, 1961-1990 temel dönemi esas alınarak, 10. ve 90. persantil değerlerine karşılık gelen sıcaklık değeri esas alınmıştır. Her bir istasyon için ayrı bir sıcaklık değeri taşıyan persantil değerlerine göre yıllık soğuk/sıcak geceler ile soğuk/sıcak gün sayıları ortaya konulmuştur. İstasyonların yaz ve tropik gün sayıları ise istasyonların günlük maksimum sıcaklık serilerinde belli bir eşik değerin üzerinde kalan gün sayıları esas alınarak belirlenmiştir.

Çizelge 2: Çalışmada kullanılan sıcaklık indisleri.

\begin{tabular}{|c|c|c|}
\hline & Ekstrem İndisi & Tanımı \\
\hline TN10p & Soğuk Geceler & $\begin{array}{l}\text { Bir yıl içinde günlük minimum sıcaklığın }<10 \text { persantil içinde kaldığı gün }\left(\mathrm{T}_{\min }<10 \text {. }\right. \\
\text { persantil) sayıları }\end{array}$ \\
\hline TN90p & Sicak Geceler & Günlük minimum sıcaklığın $>90$ persantil içinde kaldığı gün $\left(T_{\min }>90\right.$. persantil $)$ \\
\hline TX10p & Soğuk Günler & Günlük maksimum sıcaklığın 10. persantil içinde kaldığ gün $\left(\mathrm{T}_{\max }<10\right.$. persantil $)$ \\
\hline TX90p & Sicak Günler & Günlük maksimum sıcaklığın $>90$ persantil içinde kaldığ 1 gün $\left(T_{\max }>90\right.$. persantil) \\
\hline SU25 & Yaz Günleri & Günlük maksimum sıcaklığın $>25^{\circ} \mathrm{C}$ olduğu günlerin yıllık sayıları $\left(\mathrm{T}_{\max }>25^{\circ} \mathrm{C}\right)$ \\
\hline TX30 & Tropikal Gün & Günlük maksimum sicaklığın $>30^{\circ} \mathrm{C}$ olduğu gün $\left(\mathrm{T}_{\max }>30^{\circ} \mathrm{C}\right)$ \\
\hline
\end{tabular}

Ege Bölgesi’ndeki istasyonlarda 1939-2008 döneminde kullanılan 6 indise göre ekstrem sıcaklık dizilerindeki artma veya azalma yönündeki olası eğilimleri belirlemede ve istatistiksel önemini test etmede parametrik olmayan Mann-Kendall sıra ilişki katsayısından yararlanılmıştır. Mann-Kendall sınama örneklem değeri, bir dizideki uzun süreli bir eğilimin yönünü ve istatistiksel büyüklügünü vermektedir. $M-K$ sıra ilişki katsayısı tau'nun $(\tau)$ hesaplanmasında, analiz edilen $x_{i}$ elemanlı orijinal gözlem dizisinin yerine, onların küçükten büyüğe dizilmesiyle elde edilen sıra numaralarından oluşan $k_{i}$ dizileri temel alınır ve her terimin kaçıncı sırada yer aldığı bulunur. İkinci olarak $P$ istatistiği hesaplanır. $k_{i}$ dizilerindeki ilk terimin değeri ikinci terimin değerinden $N$ 'inci terime kadar, dizideki tüm terimlerin değerleriyle karşılaştırılır. $k_{i}$, $i$ aşan terimlerin sayısı bulunur ve $n_{l}$ olarak gösterilir. Aynı işlem ikinci terimin değeri ile ondan sonraki terimler arasında gerçekleştirilir ve $k_{2}$ 'yi aşan sonraki terimlerin sayısı $n_{2}$ olarak gösterilir. Bu işlem $k_{n-1}$ 'e kadar, dizideki her terim için gerçekleştirilir. $n_{i}^{\prime}$ lerin toplamı, eşitlik (1)'de gösterilen $P$ istatistiğini verir.

$$
P=\sum_{i=1}^{n} n_{i}
$$

$M-K$ sınama örneklem değeri ( $\tau$ ), $N$ ve $P$ 'den yararlanılarak aşağıdaki eşitlik (2) ile hesaplanır:

$$
\tau=\frac{4 P}{N(N-1)}-1
$$

Tau ( $\tau)^{\prime}$ nun anlamlılık sınaması $(\tau)_{\mathrm{t}}$, eşitlik (3) ile hesaplanır.

$$
\tau_{(t)}=0 \mp t_{g} \sqrt{\frac{4 N+10}{9 N(N-1)}}
$$

“Gözlem dizisinin ortalamasında herhangi bir eğilim yoktur" boş hipotezi, $(\tau)$ 'nin büyük değerleri için reddedilmekte ve hesaplanan $(\tau)$ değerinin, 0.05 ya da 0.01 düzeyinde anlamlı olmas durumunda $(\tau)>0$ ise $\operatorname{artan}(\tau)<0$ ise azalan yönde önemli bir eğilimin varlığı kabul edilmektedir (Türkeş vd., 2007). 


\section{Ege Bölgesinde Sıcaklık Ekstremlerindeki Değişim ve Eğilimler}

Ege Bölgesi’nde 1939-2008 döneminde sıcaklık indislerine göre değerlendirilen 10 istasyonun zaman serisi analizleri, sıcaklık ekstremlerinin yıldan yıla değişmekle birlikte artış veya azalış yönünde bir eğilim içinde olduğunu göstermiştir. Bölgede yıllık soğuk gün ve gece sayıları genel bir azalma, sıcak gün ve sıcak gece sayıları ise artış eğilimi içindedir. Sıcak gün ve gece sayılarındaki artış eğilimi, soğuk gün ve gece sayılarına göre çok daha belirgindir (Çizelge 3).

Çizelge 3. 10 istasyonun 6 ekstrem sicaklık indisi için 1939-2008, 1939-1973 ve 1974-2008 dönemlerine göre hesaplanan Mann-Kendall trend analizinin sonuçları. Sınama örneklem değerlerinde istatistiksel 'anlamlı' terimi en az \% 95 düzeyinde değerlendirilmiştir.

\begin{tabular}{|c|c|c|c|c|c|}
\hline İndis & Dönem & $\begin{array}{c}\text { Anlamlı artma } \\
\text { eğilimi }\end{array}$ & $\begin{array}{l}\text { Anlamlı olmayan } \\
\text { artma eğilimi }\end{array}$ & $\begin{array}{c}\text { Anlamlı olmayan } \\
\text { azalma eğilimi }\end{array}$ & $\begin{array}{c}\text { Anlamlı azalma } \\
\text { eğilimi }\end{array}$ \\
\hline \multirow{3}{*}{$\begin{array}{l}\text { Soğuk Gün } \\
\text { Say1ları (TN10p) }\end{array}$} & 1939-2008 & & 2 & 8 & \\
\hline & 1939-1973 & & & 9 & 1 \\
\hline & 1974-2008 & & 1 & 8 & 1 \\
\hline \multirow{3}{*}{$\begin{array}{l}\text { Soğuk Gece } \\
\text { Sayıları (TX10p) }\end{array}$} & 1939-2008 & & 1 & 9 & \\
\hline & $1939-1973$ & & & 7 & 3 \\
\hline & 1974-2008 & & & 10 & \\
\hline \multirow{3}{*}{$\begin{array}{l}\text { Sicak Gün } \\
\text { Sayıları (TX90p) }\end{array}$} & 1939-2008 & 7 & 3 & & \\
\hline & 1939-1973 & & 2 & 6 & 2 \\
\hline & $1974-2008$ & 9 & 1 & & \\
\hline \multirow{3}{*}{$\begin{array}{l}\text { Sicak Gece } \\
\text { Sayıları (TN90p) }\end{array}$} & 1939-2008 & 10 & 0 & & \\
\hline & 1939-1973 & 4 & 4 & 2 & \\
\hline & 1974-2008 & 10 & & & \\
\hline \multirow{3}{*}{$\begin{array}{l}\text { Yaz Günü } \\
\text { Say1ları (SU25) }\end{array}$} & 1939-2008 & 8 & 2 & & \\
\hline & 1939-1973 & & 6 & 4 & \\
\hline & $1974-2008$ & 6 & 3 & 1 & \\
\hline \multirow{3}{*}{$\begin{array}{l}\text { Tropikal Gün } \\
\text { Say1ları (TX30) }\end{array}$} & 1939-2008 & 9 & 1 & & \\
\hline & 1939-1973 & & 2 & 8 & \\
\hline & 1974-2008 & 10 & & & \\
\hline
\end{tabular}

Bölgede soğuk gün sayılarının oluşturduğu diziler ele alındığında, dizilerin genellikle yüksek sıklıklı salınımlar gösterdiği dikkati çekmektedir. Ege Bölgesi'nde 1939-2008 yılları arasında yıllık soğuk gün sayıları, Türkiye'de diğer istasyonlarda olduğu gibi 1992, 1953 ve 1948 yıllarında en yüksek sayıya ulaşmışıtır. 1955, 1999 ve 1951 ise soğuk gün sayılarının uzun yıl ortalamalarına göre önemli ölçüde azaldığg yıllardır. İncelenen istasyonlarda yıldan yıla görülen bu değişebilirlilik bölgeyi etkileyen genel hava dolaşımı ile yakından ilişskilidir.

Mann-Kendall sınamasının sonuçlarına göre, 1939-2008 yıllarını arasını kapsayan 70 yı1lık dönemde yıllık soğuk gün sayıları Afyon ve Manisa dışındaki istasyonlarda zayıf bir azalma eğilimi göstermektedir. Uşak, Dikili ve Muğla'da daha belirgin olan bu azalma eğilimi, istatistiki olarak anlamlı değildir. Bölgede son 70 yılda soğuk gün sayılarındaki eğilimler, 35'er yıllık iki dönem olarak (1939-1973 ve 1974-2008) karşılaştırıldığında, iki dönem arasında sonuçlar bakımından önemli bir farklılığın bulunmadığı gözlenir. Her iki dönemde de tüm istasyonlarda soğuk gün sayılarında istatistiki olarak anlamlı olmayan zayıf bir azalma eğilimi belirlenmiştir (Şekil 4 ve 5). Bu azalma eğilimi 1939-1973 döneminde Uşak’ta, 1974-2008 döneminde Bodrum’da \% 95 düzeyinde anlamlıdır.

Ege Bölgesi'nde yer alan 10 istasyonda soğuk gecelerin yıllık sayıları geçen yaklaşık 70 yıl süresince (1939-2008 döneminde) önemli bir değişim göstermiştir. Bu dönem içinde y1llık soğuk gece sayıları 1992, 1948 ve 1953 yıllarında maksimum sayıya ulaşmıştır. Minimum sıcaklıkların azaldığı ve Ege Bölgesi'nde en sert kışların yaşandığı bu yıllara karşılık, 1955, 1999 ve 1966 yıllarında soğuk gece sayıları uzun dönem ortalamasına göre önemli ölçüde azalma göstermiş, daha 1lıman koşullar egemen olmuştur. 


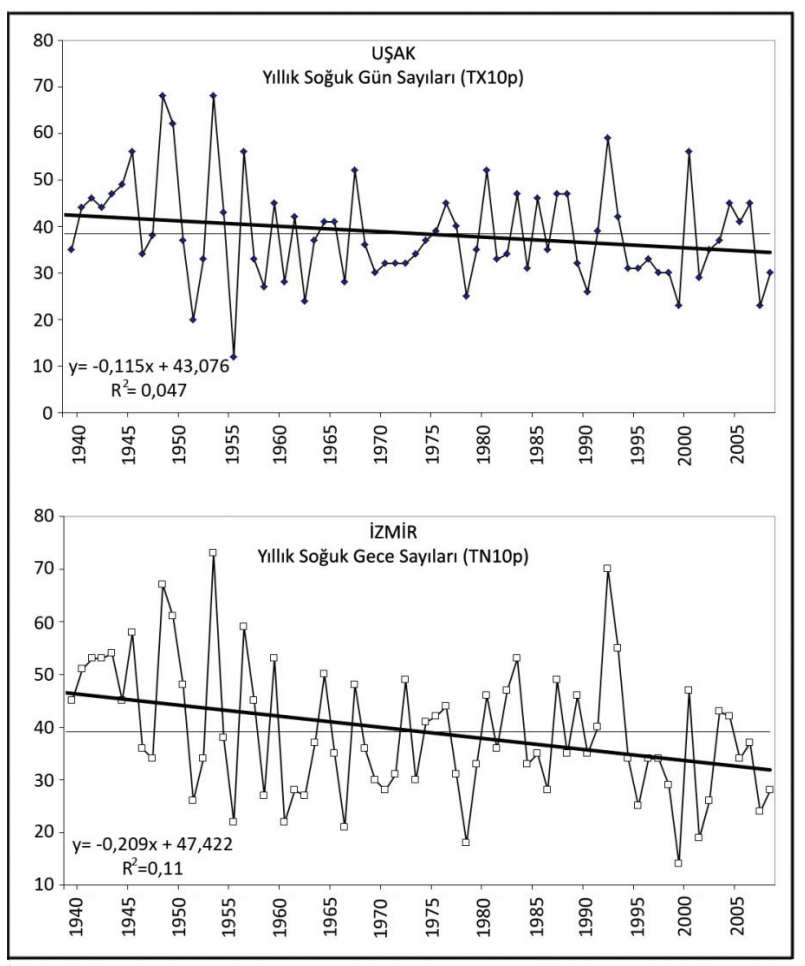

Şekil 1. Uşak'ta yıllık soğuk gün sayıları, İzmir'de yıllık soğuk gece sayılarının değişimi. İnce çizgi 1939-2008 ortalamasını, kalın çizgi doğrusal trend değerini göstermektedir.

Son 70 yılda bölgede yıllık soğuk gece sayılarındaki eğilim dikkate alındığında, Muğla dışındaki tüm istasyonlarda değerlerin zayıf bir azalma eğilimi içinde olduğu görülür. Mann-Kendall sınamasının sonuçlarına göre, ilk 35 yıllık dönemde Dikili, İzmir ve Bodrum istasyonlarında belirlenen azalma eğilimi İzmir ve Bodrum istasyonlarında istatistiki olarak anlamlıdır. Son 35 yıllık dönemde ise bölgede incelenen 10 istasyonda da yıllık soğuk gece sayılarındaki azalma eğilimi devam etmiştir (Şekil 4 ve 5).

Ege Bölgesi’nde kullanılan ekstrem sıcaklık indislerine göre ekstrem sıcaklıklarda en önemli değişim yıllık sıcak gün ve gece sayılarında gözlenmiştir. Yıllık sıcak gün ve gece sayıları son 70 yılda genel artış eğilimi içindedir. Ancak tüm istasyonlarda atmosfer salınımları ve buna bağlı hava dolaşımı ile ilişkili olarak yıllık sıcak gün/gece sayılarının arttığ1 veya azaldığg dönemler ayırt etmek mümkündür. Bölge'de yıllık sıcak gün sayılarının değişimi incelendiğinde, 1976, 1983 ve 1949 yıllarında değerlerin uzun dönem ortalamasına göre büyük ölçüde azalarak rasat süresi içindeki minimum değerlerini aldığ 1 görülür. Buna karşılık istasyonlarda 1990'lı yıllardan sonra dikkat çekici ölçüde artan yıllık sıcak gün sayıları 2008, 2007 ve 1994 yıllarında maksimum sayılarına ulaşmıştır. Örneğin ortalama yıllık sıcak gün sayıs1 37.7 gün olan Kütahya'da bu sayı 2008 yılında 85 güne, ortalama 45.5 olan Aydın'da ise 81 güne ulaşmıştır.

Mann-Kendall sınamasının sonuçlarına göre, yıllık sıcak gün sayıları tüm istasyonlarda 19392008 döneminde artma eğilimi göstermiştir. Afyon, Dikili ve Aydın dışındaki diğer istasyonlarda yıllık sıcak günü sayıları \% 99 düzeyinde olmak üzere istatistiksel olarak anlamlı bir yükselme eğilimi göstermiştir. Sıcak gün sayılarındaki eğilimler dönemler itibariyle ele alındığında, dönemler arasında önemli bir fark olduğu görülür. Ege Bölgesinde ilk 35 yıllık dönemde (1939-1973) yı1lık sicak gün sayıları Kütahya ve Muğla dışındaki diğer istasyonlarda azalma eğilimi göstermiştir. Manisa ve Aydın istasyonlarında bu azalma eğilimi istatistiksel olarak anlamlıdır. Buna karşılık 1970'li yılların 
başından itibaren günlük maksimum sıcaklıklardaki belirgin yükselme eğilimi bölgede sıcak gün sayılarında da kuvvetli bir artış eğilimini beraberinde getirmiştir. Bu nedenle son 35 yıllık dönemde (1974-2008) Dikili dışındaki tüm istasyonlarda yıllık sıcak gün sayıları istatistiksel olarak anlamlı bir artış eğilimi göstermiştir. Bu eğilim, Bodrum, İzmir, Aydın ve Muğla gibi kıyı Ege'de yer alan istasyonlarda daha da kuvvetlenmektedir.

Ege Bölgesinde en dikkat çekici değişim, günlük minimum sıcaklıkların 90. persantil aralığı içinde kaldığ 1 yıllık sıcak gece sayılarındadır. Son 70 yılda yıllık sıcak gece sayılarındaki değişim ele alındığında değerlerin 1960'lı yılların başından 1980'li yılların başına kadar uzun yıl ortalamasının altında kaldığ 1 ve bölgede yıllık sıcak gece sayılarının 1976 yılında en düşük değerini aldığı görülür. Buna karşıllı sıcak gün sayılarında olduğu gibi, sıcak gece sayılarında en dikkat çekici değişim 1980'li yılların ikinci yarısında başlamış ve bu tarihten sonra bölgede yıllık sıcak gece sayıları uzun yıl ortalamasının sürekli üzerinde kalmıştır. Bölgede yıllık sıcak gece sayıları 2008 ve 2007 yıllarında ortalamaların yaklaşık iki katına çıkarak rekor sayılara ulaşmıştır.

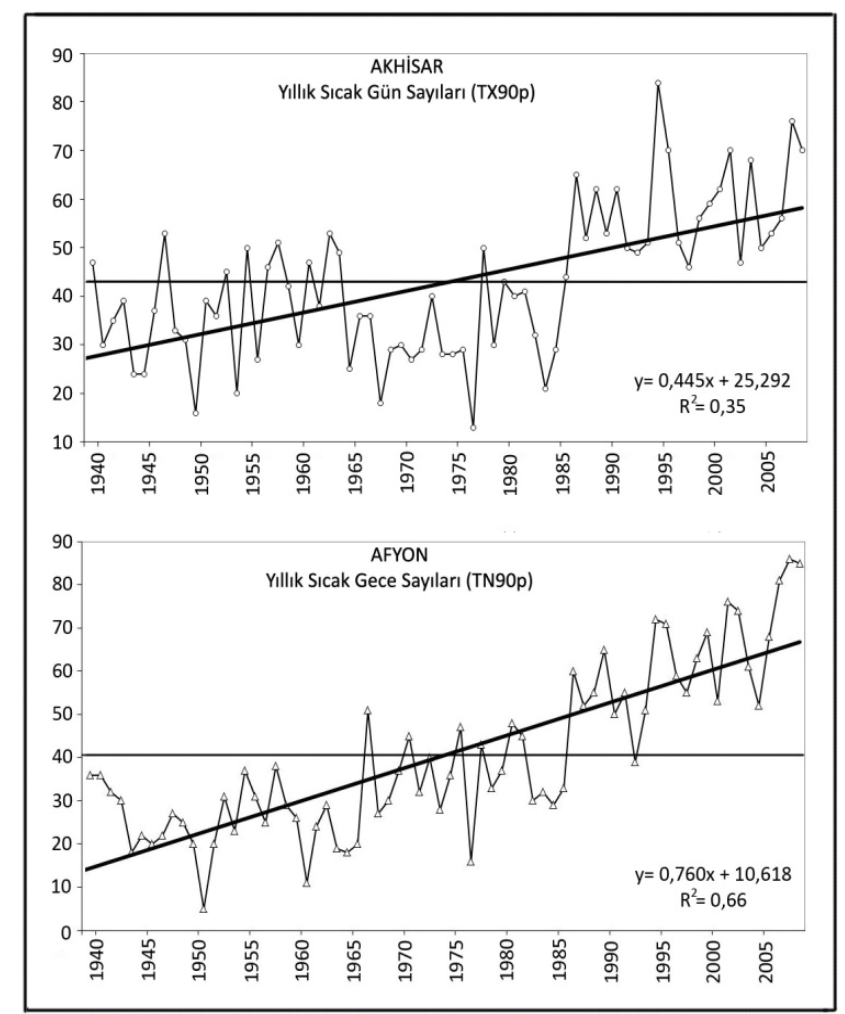

Şekil 2. Akhisar'da yıllık sıcak gün sayıları, Afyon'da yıllık sıcak gece sayılarının değişimi. İnce çizgi 1939-2008 ortalamasını, kalın çizgi doğrusal trend değerini göstermektedir.

Mann-Kendall sınamasının sonuçları da bölgede sıcak gece sayılarının belirgin bir artış eğilimi içinde olduğunu göstermektedir. Bu eğilim dönemler itibariyle bazı farklılıklar göstermektedir. 1939973 yılları arasını kapsayan ilk 35 yıllık dönemde Muğla ve Uşak dışındaki istasyonlarda yıllık sıcak gece sayıları artma eğilimi göstermiş olup bu eğilim 4 istasyonda istatistiki olarak anlamlıdır. Son 35 yıllık dönemde ise gece sıcaklıklarındaki yükselme eğilimi çok daha kuvvetlenmektedir. MannKendall sınamasının sonuçlarına göre yıllık sıcak gece sayılarındaki artış eğilimi Muğla'da \% 95 diğer 9 istasyonda \% 99 düzeyinde anlamlıdır (Şekil 5).

Günlük maksimum sıcaklığın $25^{\circ} \mathrm{C}$ eşit veya daha yüksek olduğu yıllık yaz günü sayılarının zaman serisi analizi, Ege Bölgesi’nde değerlerin 1940'lı yıllardan 1980'li yılların başına kadar azalma 
eğiliminde olduğunu göstermektedir. Bu dönem içinde 1949, 1959 ve 1965 istasyonlarda yıllık yaz günü sayılarının uzun yıllar ortalamalarına göre önemli ölçüde azaldığı yıllardır. Bölgede yıllık yaz günü sayıları 1980'lerden günümüze kadar olan dönemde ise genellikle uzun yıllar ortalamasının üzerinde kalmış, 1994 ve 2007 yıllarında maksimum sayıya ulaşmıştır. Son 70 yılda yıllık yaz günü sayıları tüm istasyonlarda artış eğilimi göstermiştir (Erlat ve Yavaşl1, 2010). Afyon ve Manisa dışında bu artış eğilimi Aydın'da \% 95, diğer istasyonlarda \% 99 düzeyinde anlamlıdır. Ancak bu eğilim dönemler itibariyle bazı farklılıklar göstermektedir. Nitekim Mann-Kendall sınamasının sonuçlarına göre 1939-1973 döneminde bölgede yaz günü sayılarında 6 istasyonda zayıf bir artış eğilimi, 4 istasyonda ise zayıf bir azalma eğilimi göstermiştir. Son 35 yılda ise 6 istasyonda istatistiki olarak anlamlı olmak üzere tüm istasyonlarda yıllık yaz günü sayıları artış eğilimi içindedir (Şekil 4-5).

Ege Bölgesi'nde son 70 yılda değişim eğilimi gösteren bir başka sıcaklık ekstremi günlük maksimum sıcaklığın $30^{\circ} \mathrm{C}$ eşit veya daha yüksek olduğu yıllık tropikal gün sayılarıdır. Bölgede yıllık tropikal gün sayıları yıllık soğuk gün-gece ve yaz günü sayılarında olduğu gibi 1970'li yılların ortalarına kadar uzun yıllar ortalamasının altında kalmış ve 1949 ile 1976 yıllarında minimum değerini almıştır. 1976 yılının serin geçen yaz mevsiminden sonra yıllık tropikal gün sayılarında belirgin bir artış gözlenmektedir. Özellikle 1994-2008 yılları aras1 tüm istasyonlarda değerlerin uzun yıl ortalamasının üzerinde kalması nedeniyle ortaya çıkan yüksek pozitif anomali değerleri ile dikkat çekicidir. İstasyonlarda maksimum tropikal gün sayıları ise aynı zamanda bölgede şiddetli kurak koşulların yaşandığı 1994 ve 2007 yıllarına aittir. Mann-Kendall trend analizinin sonuçlarına göre 1939-1973 yılları arasındaki ilk döneminde yıllık tropikal gün sayıları Kütahya ve Muğla'da zayıf bir artış eğilimi, diğer istasyonlarda ise istatistiki olarak anlamlı olmayan azalma eğilimi göstermiştir. Buna karşılık son 35 yılda bölgede tropikal gün sayılarındaki artma eğilimi ise çok daha belirgindir ve tüm istasyonlarda gözlenen artış eğilimi anlamlıdır.

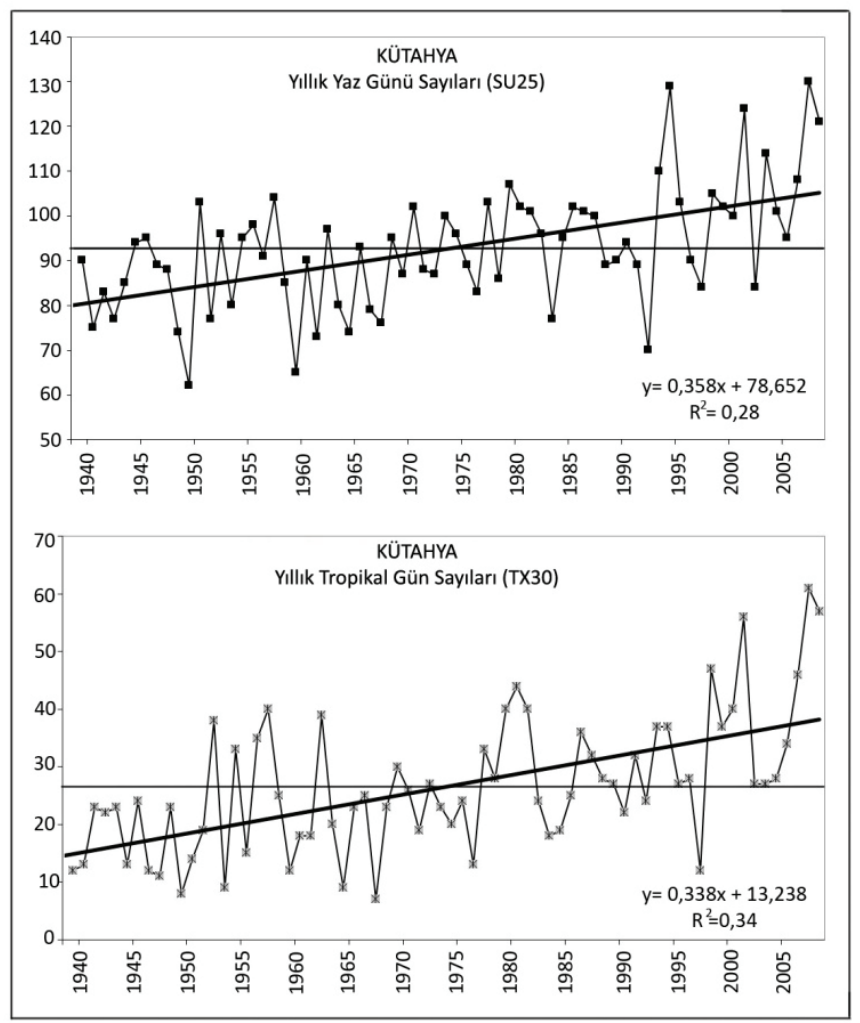

Şekil 3. Kütahya'da yıllık yaz günü ve yıllık tropikal gün sayılarının değişimi. İnce çizgi 1939-2008 ortalamasını, kalın çizgi doğrusal trend değerini göstermektedir. 

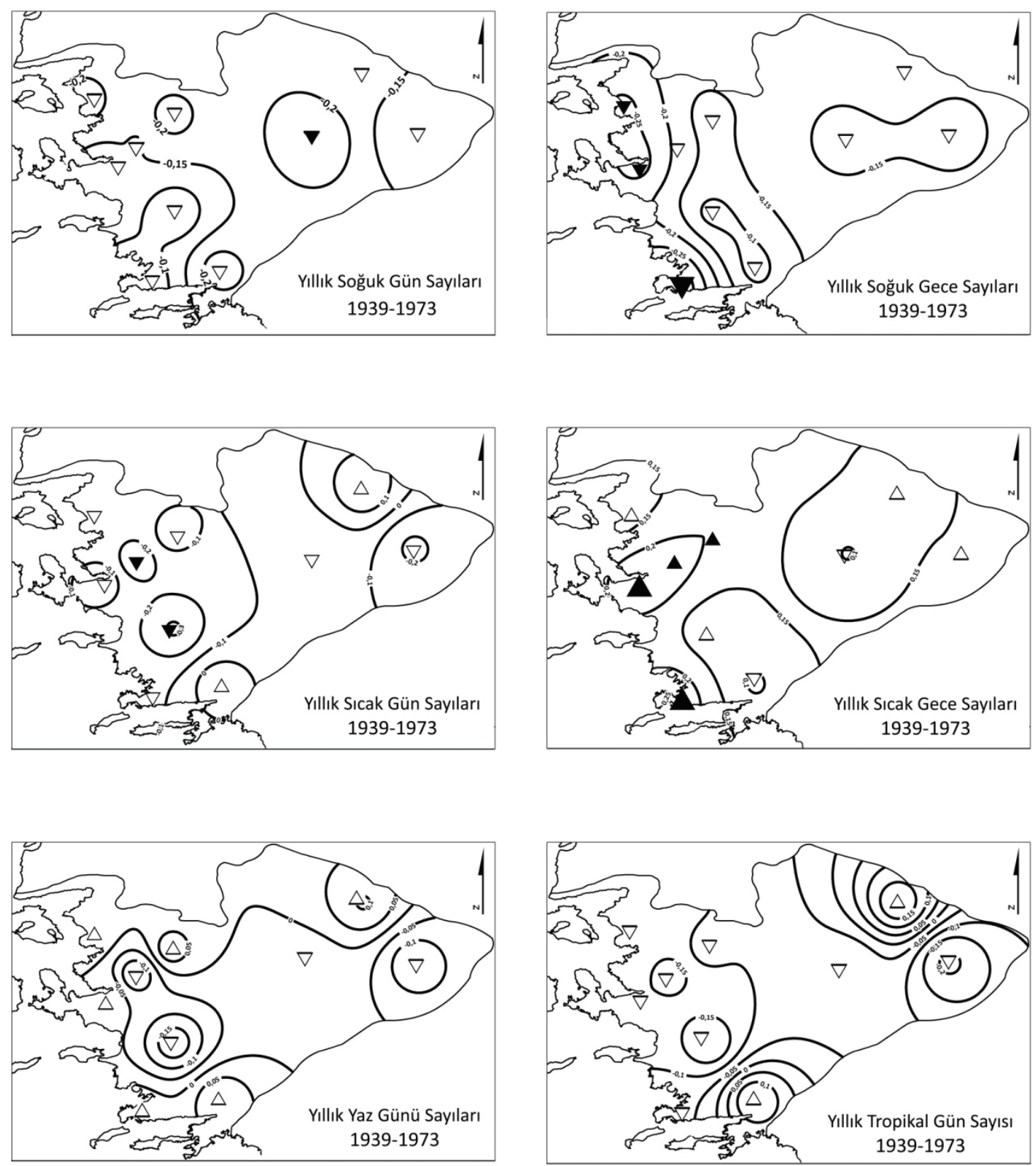

\% 1 Anlamlılık düzeyinde artış eğilimi

$\% 1$ Anlamlılık düzeyinde azalma eğilimi

$\Delta \% 5$ Anlamlılık düzeyinde artış eğilimi

$\% 5$ Anlamlılık düzeyinde azalma eğilimi

$\triangle$ Anlamlı olmayan artış eğilimi

$\nabla$ Anlamlı olmayan azalma eğilimi

Şekil 4. Ege Bölgesi'nde yer alan 10 istasyonda 1939-1973 döneminde sıcaklık ekstremlerinin Mann-Kendall testine göre belirlenen trend sonuçlarının coğrafi dağılışları. 

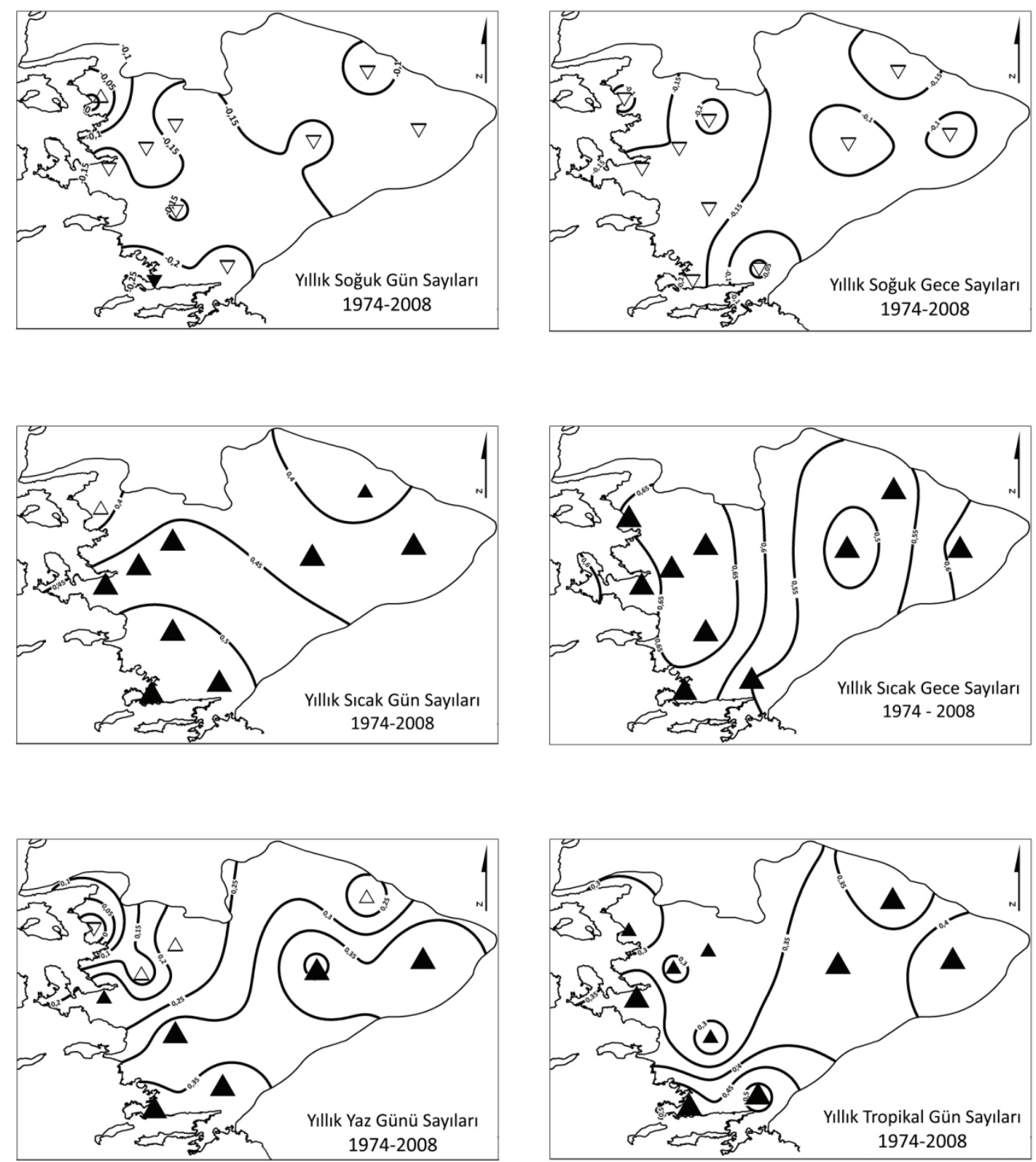

\% 1 Anlamlılık düzeyinde artış eğilimi

\% 1 Anlamlılık düzeyinde azalma eğilimi

$\Delta \% 5$ Anlamlılık düzeyinde artış eğilimi

\% 5 Anlamlılık düzeyinde azalma eğilimi

$\triangle$ Anlamlı olmayan artı̧ eğilimi

$\nabla$ Anlamlı olmayan azalma eğilimi

Şekil 5. Ege Bölgesi'nde yer alan 10 istasyonda 1973-2008 döneminde sıcaklık ekstremlerinin Mann-Kendall testine göre belirlenen trend sonuçlarının coğrafi dağılışları. 


\section{Sonuçlar}

1- Günlük sıcaklıklara uygulanan 6 ekstrem sıcaklık indisinin sonuçları Ege Bölgesi'nde ekstrem sıcaklıkların 1939-2008 döneminde değiştiğini göstermektedir. Bu değişim esas olarak sıcaklıklardaki soğuk ekstremlerin gerçekleştiği gün sayılarındaki azalmadan çok sıcak ekstremlerin yaşandığı gün sayılarındaki artış ile ilişkilidir.

2- 1938-2008 dönemini kapsayan 70 yıl incelendiğinde, Ege Bölgesi’nde yıllık soğuk gün sayılarında Afyon ve Manisa dışındaki istasyonlarda zayıf bir azalma eğilimi bulunduğu görülür. Zaman dizisi çizimlerinde 1992 yılı sonrasında yıllık soğuk gün sayılarındaki azalma eğilimi dikkat çekicidir. Özellikle 1999 ile 2007 yıllarında istasyonlarda yıllık soğuk gün sayılarının rasat süresi içindeki minimum değerlerini aldığı görülmektedir. Bölgede 1939-2008 döneminde y1llık soğuk gece sayıları da azalma eğilimi göstermiştir ve bu eğilim soğuk gün sayılarına göre daha kuvvetlidir. Soğuk gece sayılarının istatistiki olarak anlamlı ölçüde azaldığı istasyonlar kıyı Ege'de yer almaktadır.

3- Çalışma dönemi boyunca Ege Bölgesi’nde yıllık sıcak gün sayıları, yıllık soğuk gün/gece sayılarından farklı olarak istatistiki olarak anlamlı artış eğilimi göstermiştir. İstasyonlarda anlamlı artış eğilimleri 1970'li yılların ortalarından itibaren belirginleşmektedir. $\mathrm{Bu}$ durum Akdeniz iklimi nedeniyle 1lık kışların ve sıcak yazların egemen olduğu bölgede gündüzleri ölçülen sıcaklıkların daha da yükseldiğini göstermektedir. Ege Bölgesi'nde ekstrem sıcaklıkların oluşturduğu dizilerde en dikkat çekici sonuçlar yıllık sıcak gece sayılarına aittir. İstasyonların zaman dizisi çizimlerinde açıça görülen ortak ve anlamlı 1sınma eğilimi 1970'li yılların ortalarından itibaren kuvvetlenmektedir. İncelenen 10 istasyonunun tümünde 2008, 2007 ve 1994 yılları, +1 veya +2 standart sapma değeri ile en yüksek pozitif anomali değerini göstermiştir. Günlük minimum sıcaklığın $>90$ persantil içinde kaldığı gün sayılarındaki bu artış, bölgede gece sıcaklıklarının dramatik bir şekilde yükseldiğini ortaya koymaktadır.

4- Ege Bölgesi'nde son 70 yılda yıllık tropikal gün ve yaz günü sayılarındaki belirgin artış eğilimi soğuk ekstremlerden çok sıcak ekstremlerin daha hızlı değiştiğinin bir başka göstergesidir. Özellikle 1970'li yılların ikinci yarısı, tropikal gün ve yaz günü sayılarındaki pozitif anomali değerleri ve istatistiki olarak anlamlı artış eğilimleri ile karakterize olmaktadır.

5- Elde edilen sonuçlar dünyanın birçok bölgesinde özellikle Avrupa'da yapılan çalışmaların sonuçları ile uyumludur. Nitekim tüm dünyada 1953-1993 döneminde gece sıcaklıkları gündüz sıcaklıklarının yaklaşı iki katı oranında artış göstermiştir (Folland, 2001). Avrupa için yapılan çalışmalar da, 20. yüzyılda en serin yazlardan biri olan 1976 yılından sonra Avrupa'da soğuk gün/gece sayılarından çok, sıcak gün ve gece sayılarından oluşan sıcak ekstremlerin arttığını ortaya koymaktadır (Yan ve vd., 2002).

6- Ege Bölgesi’nde sıcaklık ekstremlerindeki artışın en önemli nedeni olarak insan etkinlikleri sonucunda atmosferin bileşiminde ortaya çıkan önemli değişiklikler ve buna bağlı olarak küresel yüzey sıcaklıklarında 19. yüzyılın sonlarında başlayan ısınma eğilimi gösterilebilir. 1860 yılından bu yana tutulan küresel yıllık ortalama sicaklık kayıtları, en sıcak 10 y1lın 1997 ile 2009 yılları arasında yaşandığını göstermektedir. Bölgede sıcak gece sayılarında gözlenen belirgin artış eğiliminde, aynı zamanda kentsel 1sı adalarının da katkısı olduğu söylenebilir. Değerlerdeki yıllar arası yüksek değişkenlik ise bölgede ekstrem sıcaklıklardaki değişim üzerinde küresel sıcaklık artışı ve kentsel isı adaları yanında atmosfer dolaşımındaki anomalilerinde etkili olduğunu ortaya koymaktadır. Yapılan çalışmalar Akdeniz Havzası boyunca etkili olan atmosfer dolaşımı tipleriyle bağlantılı değişimler ve anomaliler ile iklim sistemindeki geri besleme mekanizmalarının ekstrem sıcaklıklardaki değişimde kentsel 1sı adaları kadar belirleyici olduğunu göstermektedir. Örneğin Ege Bölgesi'nde sıcak gecelerin rasat süresi içinde maksimum sayılarına ulaştığı 2007, subtropikal jet akımlarının daha yüksek enlemlere kayması nedeniyle Akdeniz havzasında kuvvetli antisiklonik koşulların etkili olduğu bir 
yıldır. Havza üzerinde antisiklonik dolaşım modeli kuzey Afrika üzerinden sıcak hava kütlelerinin Doğu Akdeniz'e doğru taşınmasına yol açmış ve bu nedenle 2007 yılı yazında Balkanlar ve Yunanistan'da rekor sıcaklık değerleri kaydedilmiştir. Ayrıca kış yağışlarının azaldığı ve kurak koşulların etkili olduğu yıllarda buharlaşma (latent) için harcanan enerjini azalmasının, hava sıcaklıklarının daha da yükselmesinde etkili olduğu düşünülmektedir (Luterbacher vd., 2007; Fischer vd., 2007). Ege Bölgesi'nde sıcak gün ve gece sayılarının maksimum sayıya ulaştığ1 1994 ve 2007 yıllarının ortak özellikleri şiddetli kuraklıklar ile karakterize olmalarıdır (Türkeş vd.,2007).

7- SRES A2 emisyon senaryosuna göre oluşturulan bölgesel iklim modelinin projeksiyonunda, atmosferde artan sera gazlarının konsantrasyonu nedeniyle 21. yüzyılın sonuna kadar Akdeniz Havzası'nda ekstrem sıcaklıkların değişeceği belirtilmektedir. Bu değişim özellikle sıcak dalgalarının daha uzun, şiddetli ve daha sık tekrarlanması ve günlük maksimum sıcaklıklardaki yükselmeye bağlı olarak insanlarda 1sı stresinin bazı kentlerde \% 500 artacağı yönündedir. Akdeniz ikliminde kurak geçen yazların nem geri besleme mekanizması ile maksimum sıcaklıkların daha da yükselmesine önemli katkı sağlayacağı öngörülmektedir (Diffenbaugh vd., 2007).

8- Bölgede ekstrem sıcaklık özelliklerindeki bu değişimin birçok çevresel, sosyal ve ekonomik etkilerinin olacağı söylenebilir. Bu etkilerin başında tarım için gerekli suyun azalması, orman yangınlarının daha sık gerçekleşmesi, yılın sıcak döneminde enerji tüketiminde artış ve tropik hastalıkların daha fazla ortaya çıkma riski gelmektedir. Bu değişim özellikle büyük kentlerde yaşayan insanların sağlık koşulları üzerinde olumsuz etkiler yaratacağı açıktır.

\section{Kaynaklar}

Alexander, L. V., Zhang, X., Peterson, T. C., Caesar, J., Gleason, B., Tank, K., Haylock, M., Collins, D., Trewin, B., Rahimzadeh, F., Tagipour, A., Rupa Kumar, K., Revadekar, J., Griffiths, G., Vincent, L., Stephenson, D. B., Burn, J., Aguilar, E., Brunet, M., Taylor, M., New, M., Zhai, P., Rusticucci, M.. ve Vazquez- Aguirre, J. L. 2006. Global observed changes in daily climate extremes of temperature and precipitation. Journal of Geophysical Research 111, D05109, doi:10.1029/2005JD006290.

Bartholy, J. ve Pongracz, R. 2007. Regional analysis of extreme temperature and precipitation indices for the Carpathian Basin from 1946 to 2001. Global and Planetary Change 57: 83-95.

Brunet, M., Saladie, O., Jones, P.D., Sigro, J., Aguilar, E., Moberg, A., Lister, D.H., Walther A., Lopez, D. ve Almarza C. 2006. The development of a new dataset of Spanish daily adjusted temperature series (SDATS) (1850-2003). International Journal of Climatology 26: 1777-1802.

Diffenbaugh, N. S., Pal, J. S., Giorgi, F. ve Gao, X. 2007. Heat stress intensification in the Mediterranean climate change hotspot. Geophysical Research Letters 34, L11706.

Erlat, E. ve Yavaşl1, D.D. 2010. Ege Bölgesi’nde tropikal gün ve yaz günü sayısındaki değişim ve eğilimler. Ege Coğrafya Dergisi Cilt 18, Say1 1-2: 1-15.

Fisher, E.M., Seneviratne, S.I., Vidale, P.L., Luthi, D. ve Schar, C. 2007. Soil moisture - atmosphere interactions during the 2003 European summer heat wave. Journal of Climate 20: 5081-5099.

Folland, C. K., Karl T. R. ve diğer yazarlar 2001. Observed climate variability and change. Climate Change 2001: The scientific Basis. Contribution of working Group I to the Third Assessment Report of the Intergovernmental Panel on Climate Change, J.T. Houghton et al., Eds., Cambridge University Press, sayfa 99-181.

Frich, P., Alexander, L.V., Della-Marta, P., Gleason, B., Haylock, M., Klein Tank, A. M. G. ve Peterson, T. 2002. Observed coherent changes in climatic extremes during the second half of the twentieth century. Climate Research 19:193212.

IPCC 2007. Climate Change 2007: The Physical Science Basis. Contribution of Working Group I to the Fourth Assessment Report of the Intergovernmental Panel on Climate Change [Solomon, S., D. Qin, M. Manning, Z. Chen, M. Marquis, K.B. Averyt, M. Tignor ve H.L. Miller (editörler)]. Cambridge University Press, Cambridge, United Kingdom and New York, ABD.

Kiktev, D., Sexton, D. M. H., Alexander, L. ve Folland C. K. 2003. Comparison of modeled and observed trends in indices of daily climate extremes", Journal of Climate 16: 3560-3571.

Kioutsioukis, I., Melas, D. ve Zerefos, C. 2009. Statistical assessment of changes in climate extremes over Greece (19552002). International Journal of Climatolology DOI: 10.1002/joc.2030. 
Kuglitsh, F. G., Toreti, A., Xoplaki, E., Della-Marta, P. M., Zerefos, C. S., Türkeş, M. ve Luterbacher, J. 2010. Heat wave changes in the eastern Mediterranean since 1960. Geophysical Research Letters 37, L04802, doi:10.1029/2009GL041841.

Luterbacher, J., Liniger, M.A., Menzel, A., Estrella, N., Della-Marta, P.M., Pfister, C., Rutishhauser, T. ve Xoplaki, E., 2007. Exceptional European warmth of Autumn 2006 and Winter 2007: historical context, the underlying dynamics and its phenological impacts. Geophysical Research Letters 34, L12704.

Nastos, P. T. ve Matzarakis, A. P. 2008. Variability of tropical days over Greece within the second half of the twentieth century. Theoretical and Applied Climatology 93: 75-89.

Peterson, T.C., Folland, C., Gruza, G., Hogg, W., Mokssit, A. ve Plummer, N. 2001. Report on the Activities of the Working Group on Climate Change Detection and Related Reporters 1998-2001. WMO, Rep. WCDMP-47, WMO-TD 1071, Cenova, İsviçre.

Şensoy, S., Demircen, M. ve Alan, Ü. 2008. Trends in Turkey Climate Extreme Indices from 1971 to 2004. IV. Atmosfer Bilimleri Sempozyumu (25-28 Mart 2008) Bildiri Kitabı 453-460.

Yan Z, Jones, P, Davies, T, Moberg, A, Bergstrom, H, Camuffo, D, Cocheo C, Maugeri M, Demaree, G, Verhoeve, T, Thoen, E, Barriendos, M, Rodriguez, R, Martin-Vide, J, ve Yang, C. 2002. Trends of extreme temperatures in Europe and China based on daily observations. Climatic Change 53: 355-392. 
